Review

\title{
GENE SILENCING: CONCEPTS, APPLICATIONS, AND PERSPECTIVES IN WOODY PLANTS
}

\author{
Amancio José de Souza ${ }^{1}$; Beatriz Madalena Januzzi Mendes²; Francisco de Assis Alves \\ Mourão Filho ${ }^{3 *}$ \\ ${ }^{1}$ USP/ESALQ - Programa de Pós-Graduação em Fitotecnia. \\ ${ }^{2}$ USP/CENA - Laboratório de Biotecnologia Vegetal, C.P. 96 - 13400-970 - Piracicaba, SP - Brasil. \\ ${ }^{3}$ USP/ESALQ - Depto. de Produção Vegetal, C.P. 09 - 13418-900 - Piracicaba, SP - Brasil. \\ "Corresponding author 〈famourao@esalq.usp.br>
}

\begin{abstract}
RNA interference, transcriptional gene silencing, virus induced gene silencing, and micro RNAs comprise a series of mechanisms capable of suppressing gene expression in plants. These mechanisms reveal similar biochemical pathways and appear to be related in several levels. The ability to manipulate gene silencing has produced transgenic plants able to switch off endogenous genes and invading nucleic acids. This powerful biotechnological tool has provided plant breeders and researchers with great opportunity to accelerate breeding programs and developmental studies in woody plants. This research work reports on gene silencing in woody plants, and discuss applications and future perspectives.
\end{abstract}

Key words: RNAi, miRNA, siRNA, genetic transformation, virus resistance

\section{SILENCIAMENTO GÊNICO: CONCEITOS, APLICAÇÕES E PERSPECTIVASEM PLANTAS LENHOSAS}

\begin{abstract}
RESUMO: RNA de interferência, silenciamento gênico transcricional, silenciamento gênico induzido por vírus e micro RNAs compõem uma série de mecanismos capazes de suprimir a expressão gênica em plantas. Estes mecanismos revelaram rotas metabólicas parecidas e interagem em vários níveis. A capacidade de manipular técnicas de silenciamento gênico tem produzido plantas transgênicas capazes de suprimir a expressão de genes endógenos e ácidos nucléicos invasores. Esta poderosa ferramenta biotecnológica tem ofertado a possibilidade de acelerar programas de melhoramento e pesquisas em desenvolvimento de plantas lenhosas. Este trabalho visa revisar pesquisas de silenciamento gênico em plantas lenhosas e discutir aplicações e rumos futuros.

Palavras-chave: RNAi, miRNA, siRNA, resistência a vírus, transformação genética
\end{abstract}

\section{INTRODUCTION}

The discovery of mechanisms that suppress gene activity in plants has extended the horizon for research on control of gene expression (Mansoor et al., 2006). Gene silencing (GS) is defined as a molecular process involved in the down regulation of specific genes, and probably evolved as a genetic defense system against viruses and invading nucleic acids (Brigneti et al., 1998; Voinnet et al., 2000; Waterhouse et al., 2001; Wassenegger, 2002). Currently, there are several routes of GS identified in plants, such as: posttranscriptional gene silencing or RNA interference (PTGS or RNAi) (Vaucheret et al., 2001), transcriptional gene silencing (Vaucheret \& Fagard, 2001), microRNA silencing (Bartel, 2004), and virus induced gene silencing (Burch-Smith et al., 2004). All these pathways play an important role at the cellular level, affecting differentiation, gene regulation (Bartel, 2004), and protection against viruses and transposons (Waterhouse et al., 2001).

There are numerous possible applications for GS in plants. Initially, the main research focus was the production of virus resistant plants through genetic transformation (Lindbo \& Dougherty, 1992; Angell \& Baulcombe, 1997; Gutiérrez-E et al., 1997; Ravelonandro et al., 2000; Scorza et al., 2001). GS has also been used in food quality modification such as the reduction of caffeine levels in coffee beans (Ogita et al., 2003), and to increase the nutritional value of corn protein and tomatoes (Segal et al., 2003; Davuluri et al., 2005). Research on forest tree yield and quality has included the study of GS related to lignin synthesis. On the other hand, research on fruit 
crops has targeted applications of GS on viral and bacterial resistance, and physiological aspects such as selffertility. The study of plant gene function by affecting gene expression through silencing techniques (PTGS / RNAi and VIGS) has also been present in recent lines of investigation (Robertson, 2004).

This review reports and discusses the main molecular mechanisms involved in plant GS as well as the research focused on woody plants. Perspectives of the application of this technology in woody plant improvement are also considered.

\section{MECHANISMS OF GENE SILENCING}

Some early findings regarding GS occurred when a team of researchers tried to obtain transgenic petunias with greater amounts of anthocyanin pigments, by amplifying the gene activity of chalcone synthase (Napoli et al., 1990). Instead of obtaining deeper purples in the petals, white or chimeric flowers were produced. Apparently, the transgene was not expressed, and ended up silencing a homologue endogenous gene. The phenomenon, named "co-suppression", was unstably transmitted within generations leading to the hypothesis that it was mediated by a nucleic acid, presumably RNA (Gura, 2000).

Similar phenomena were named "quelling" in fungi (Romano \& Macino, 1992; Cogoni \& Macino, 1997) and "RNA interference" (RNAi) in Caenorhabditis elegans (Fire et al., 1998). The research indicated that the presence of double stranded RNA (dsRNA), a non-occurring form in normal cells, was related to the silencing of sequence homologue genes. The fact that the phenomenon seemed to be triggered by the presence of doubled stranded RNA (dsRNA) suggested that this could be originally a defense mechanism against viruses and transposable elements, since these originate dsRNA (Waterhouse et al., 2001).

Most of the GS phenomena are related to RNA activity within the cell. Therefore, the term RNA silencing is often used to describe GS and comprise all mechanisms by which RNA sequences regulate gene expression, except those sequences characterized as mRNAs, tRNAs, or ribosomal RNAs (Galun, 2005). Genetic and biochemical studies have confirmed that the mechanisms of RNAi, co-suppression, and virus-induced gene silencing are similar. Moreover, the biological pathways underlying dsRNA-induced GS exist in many, if not most, eukaryotic organisms (Hannon, 2002). The study of similar phenomena in different organisms (Caenorhabditis elegans, Neurospora crassa, Drosophila melanogaster, Arabidopsis thaliana and Petunia $x$ hybrida) allowed the proposal of models for different but interacting forms of silencing.

\section{RNA interference}

According to the present model, the RNA interference pathway starts with the presence of dsRNA in the cytoplasm that vary in length and origin (Waterhouse et al., 1998; Meister \& Tuschl, 2004; Lodish et al., 2005). The basic pathway for RNAi is shown in yellow in Figure 1 (A, B, C). This particular molecule is recognized by the Dicer enzyme, a member of the RNase III family of nucleases that specifically cleave double-stranded RNAs, and is evolutionarily conserved in worms, flies, plants, fungi, and mammals (Bernstein et al., 2001). This enzyme cleaves the dsRNA into shorter RNA duplexes of 21 to 28 nucleotides, which have 5' phosphate and 2-nucleotide 3' overhangs (Hamilton \& Baulcombe, 1999; Bernstein et al., 2001; Elbashir et al., 2001; Meister \& Tuschl, 2004). These short RNA duplexes are known as short interfering RNA (siRNA) (Baulcombe, 2004).

Several organisms contain more than one Dicer gene, with each Dicer preferentially processing dsRNAs that come from specific source (Meister \& Tuschl, 2004; Margis et al., 2006). In Arabidopsis, for instance, DCL2 and DCL3 Dicer-like proteins seem to process long dsRNA such as transcripts containing inverted repeats (Figure 1A) or intermediates formed during RNA virus replication (Figure 1B) (Hannon, 2002). DCL2, DCL3, and DCL4 have similar functions in Arabidopsis, acting in siRNA processing and establishing and maintaining DNA methylation (Henderson et al., 2006). On the other hand, DCL1 processes miRNAs precursors exported from the nucleus (Figure 1D) (Xie et al., 2004).

After Dicer processes the dsRNA, the siRNAs are subsequently rearranged into the RNA-induced silencing complex (RISC) (Figure 1E) (Hammond et al., 2000; Nykänen et al., 2001). The RISC complex was originally identified through fractionation of sequence specific nuclease activity from $D$. melanogaster extracts (Hammond et al., 2001; Tolia \& Joshua-Tor, 2006). The characterization of RISC includes the presence of an Argonaute protein family member and a guide strand (antisense to the target RNA) of a small RNA (Tolia \& Joshua-Tor, 2006). The RISC complex is responsible for the targeting and cleavage of sequence specific mRNA within the cell (Figure 1F) (Martinez \& Tuschl, 2004). RISC acts by cleaving the target mRNA in the middle of the complementary region, ten nucleotides upstream of the nucleotide paired with the 5' end of the guide siRNA (Elbashir et al., 2001). At least one protein from the Argonaute family, present in the RISC complex, probably acts as endonuclease, cleaving the target mRNAs (often referred to as the Slicer function) (Ronemus et al., 2006; Daneholt, 2007). This cleavage leads to silencing of 
the target mRNA by preventing read-through of the message by the translational machinery, resulting in mRNA destruction (Figure 1G) (Tolia \& Joshua-Tor, 2006). Normally there is a bias towards the loading of the antisense strand of the RNA short duplex produced by Dicer into the RISC complex. The antisense 5' end is less stable than the sense end of the duplex, favoring the antisense loading into the RISC complex after helicase processing (Khvorova et al., 2003; Schwarz et al., 2003; Bartel, 2004; Meister \& Tuschl, 2004). However, loading may occur by both ends into the RISC complex.

GS has an additional characteristic in plants: The silencing signal has the ability to spread systemically (Voinnet et al., 1998). The nature of the systemic signal in plants was not yet determined. However, it may be concluded that these phenomena requires firstly a system to pass a signal from cell to cell, and secondly a strategy to amplify the signal (Hannon, 2002). Apparently, it seems that the short dsRNA formed by DICER might be the answer (Figure 1H). Some evidence suggests other hypotheses. For instance, the initial long dsRNA strands could be amplified and transported with the help of movement proteins (Figure 1I) (Waterhouse et al., 2001). It has been demonstrated that plants have RNA dependent RNA polimerases (RdRP) - like enzymes that probably work amplifying the initial dsRNA thus transmitting the silencing signal (Figure 1J) (Matzke et al., 2001; Cerutti, 2003). RdRP proteins could possibly mediate primerdependent (using siRNA) and primer-independent ( $a b-$ errant RNA features) mechanisms of RNA silencing (Figure 1J and 1K) (Baulcombe, 2007). The production of dsRNA from single stranded template (ssRNA) is probably linked to the primer-independent process, so that silencing can be initiated in virus-infected plants or with transgenic RNAs. The differentiation mechanism between the viral and the transgenic RNAs targeted for silencing from the non-silenced endogenous RNAs is not clear, perhaps the ssRNA targeted for silencing presents aberrant features, which the enzyme is able to recognize (Baulcombe, 2007).

Recent models classify different siRNA in primary and secondary types (Figure $1 \mathrm{~L}$ and $1 \mathrm{M}$ ). Primary siRNA are generated from the activity of the Dicer enzyme, while secondary siRNA would be generated from a different pathway having the mandatory involvement of a RNA-dependent RNA Polymerase (Pak \& Fire, 2007). Secondary siRNA is likely to regulate gene expression in cases where amplification of the silencing signal is important, they would also be important in cases where the original trigger for RNAi is absent (Baulcombe, 2007). The common reports of GS resulting from plant transformation were proposed to be caused by the integration of multiple transgenes as inverted repeats leading to the formation of dsRNA (Waterhouse et al., 1998). This would initiate the RNAi pathway as previously discussed.

\section{Transcriptional gene silencing}

DNA methylation and chromatin remodeling play a major role in transcriptional gene silencing (TGS), blocking gene expression (Waterhouse et al., 2001). In TGS, silenced transgenes coding regions and promoters are densely methylated (Kooter et al., 1999). It is also proposed that the increase in DNA methylation possibly induces formation of heterochromatin, which is associated to TGS (Ye et al., 1996; Wassenegger \& Pélissier, 1998; Wassenegger, 2000). DNA methylation promotes protein binding that recognizes methylated cytosine, leading to chromatin remodeling (Alberts et al., 2002), thus avoiding the binding of transcription factors (Kooter et al., 1999). In Pinus radiata, the extent of DNA methylation increases in mature meristematic regions when compared to juvenile regions, suggesting that methylation is involved in developmental control and aging processes (Fraga et al., 2002).

Heterochromatin can be defined as condensate chromosomal regions, which are densely stained and known for genetic inactivity (Griffiths et al., 1998). Methylation, acetylation, phosphorilation and ubiquitination of core histones $\mathrm{H} 2 \mathrm{~A}, \mathrm{H} 2 \mathrm{~B}, \mathrm{H} 3$ and $\mathrm{H} 4$ are implicated in gene regulation (Lippman \& Martienssen, 2004). These chemical modifications within histones alter the packing state of DNA between euchromatin (active DNA) and heterochromatin (inactive DNA). Histone acetylation is one factor that can destabilize chromatin structure by altering the charge composition within chromatin (Alberts et al., 2002). Chemical alterations within histone tails may function as signals for chromatin remodeling complexes, which are responsible for regulating the accessibility of the cells transcriptional machinery to the DNA (Alberts et al., 2002). At least in plants there is a direct link between DNA methylation and histone methylation suggesting that they play a common role in transcriptional gene silencing (Lippman \& Martienssen, 2004).

Early research suggested that TGS and PTGS (RNAi) were independent phenomena. However, it was later discovered that viruses and transgenes originating dsRNA induced both TGS and PTGS (RNAi), suggesting that these could be alternative, but not exclusive routes of regulation (Vaucheret \& Fagard, 2001). RNA silencing has also been associated to de novo DNA methylation in plants (Chan et al., 2004). The fact that almost all DNA and histone methylation events are confined to transposons and repeats suggests a role 
for RNAi as a targeting mechanism for specific sequence chromatin remodeling or TGS (Lippman \& Martienssen, 2004). Research carried out on Schizosaccharomyces pombe and Arabidopsis indicates that the RNA-directed DNA methylation (RdDM) signal transmitted from the cytoplasm to the nucleus is most likely siRNA (Figure 1N) (Xie et al., 2004). Additionally, chromatin-based silencing guided by siRNAs may act as a genomic defense system to suppress mobile genetic elements or invasive DNA (Dawe, 2003; Schramke \& Allshire, 2003).

On the other hand, RNAi effector complex termed RITS (Figure 1O) (RNA-induced Initiation of Transcriptional gene Silencing) has been described, and it seems to be required for heterochromatin assembly in fission yeast (Schizosaccharomyces pombe) (Verdel et al., 2004). This same work suggests a mechanism for the role of the RNAi machinery and small RNAs in targeting of heterochromatin complexes and epigenetic gene silencing at specific chromosomal loci. The present model suggests similarities between the RISC and the RITS complex. The RITS complex would target DNA sequences and/or nascent RNA transcripts initiating heterochromatin formation and consequently TGS. It is possible that similar phenomenon occurs in plants since at least ten members of the Argonaute protein family that occur in Arabidopsis thaliana resemble proteins present in RITS (Baulcombe, 2004; Verdel et al., 2004).

\section{Micro RNA}

MicroRNAs (miRNAs) are $22 \mathrm{nt}$ endogenous RNAs that can play important regulatory roles in animals and plants by cleavage or translational repression of mRNA (Figure 1P and 1F) (Bartel, 2004; Duan et al., 2006). These molecules comprise one of the more abundant classes of gene regulatory molecules in multicellular organisms. MicroRNAs were firstly reported in Caenorhabditis elegans by the discovery that the lin-4 gene coded a pair of small RNAs instead of a protein (Lee et al., 1993). Further evidence showed that these small RNA products had antisense complementarity and were responsible for the translational regulation of another gene, the lin-14 (Lee et al., 1993; Wightman et al., 1993). Lin-14 mRNAs levels were not altered but the protein output of the gene was reduced.

In plants, miRNAs are involved in the control of leaf and flower development (Aukerman \& Sakai, 2003; Emery et al., 2003; Palatnik et al., 2003; Chen, 2004). It appears that a substantial fraction of the gene regulatory molecules in plants could be RNA rather than protein transcription factors (Bartel, 2004). Plant $\sim 22$ nt long miRNAs are endogenously expressed and po- tentially processed from one arm foldback precursors. These molecules are also generally conserved in evolution and come from regions of the genome distinct from previously annotated genes (Reinhart et al., 2002). Recent data demonstrates that miRNAs are also involved in other mechanisms such as stress and environmental change response (Bonnet et al., 2006).

MicroRNAs and siRNAs have a shared central biogenesis and can perform interchangeable biochemical functions. Therefore, these two classes of silencing RNAs cannot be distinguished by either their chemical composition or mechanism of action (Bartel, 2004). However, some distinction can be made regarding origin, evolutionary conservation and types of genes they silence: (i) miRNAs derive from genomic loci distinct from other recognized genes, whereas siRNA often derive from mRNAs, transposons, viruses, or heterochromatic DNA; (ii) miRNAs are processed from transcripts that can form local RNA hairpin structures (Figure 1D), whereas siRNAs are processed from long bimolecular RNA duplexes or extended hairpins; (iii) a single stranded mature miRNA is generated from each miRNA hairpin precursor molecule, whereas a multitude of siRNA duplexes are generated from each siRNA precursor molecule, leading to many different siRNA accumulating from both strands of this extended dsRNA; (iv) miRNA sequences are nearly always conserved in related organisms, whereas endogenous siRNA sequences are rarely conserved (Bartel \& Bartel, 2003).

MicroRNAs in plants are probably processed by DCL1 (Dicer) in the nucleus (Papp et al., 2003), and its molecular pathway is exclusively linked to a dsRNA binding protein (HYL1) (Vazquez et al., 2004). Mature miRNA can be loaded into RISC or microRNA effector complex (miRNP), the first directs mRNA cleavage and the second is responsible for translational repression (Meister \& Tuschl, 2004). Preferentially plant miRNA use RNA target cleavage instead of translational suppression and are nearly perfectly paired to their targets (Rhoades et al., 2002).

Recently, it has been demonstrated that the modification of plant endogenous miRNA precursors to interfere with viral mRNA sequences can confer virus resistance in Arabidopsis thaliana (Niu et al., 2006). These modified miRNA are termed artificial miRNA and this technique will open new perspectives for engineering viral resistant plants.

\section{Virus induced gene silencing (VIGS)}

Virus induced gene silencing is a technique designed to suppress gene expression and study gene function in plants (Robertson, 2004). VIGS can be defined as the silencing of endogenous plant genes initi- 


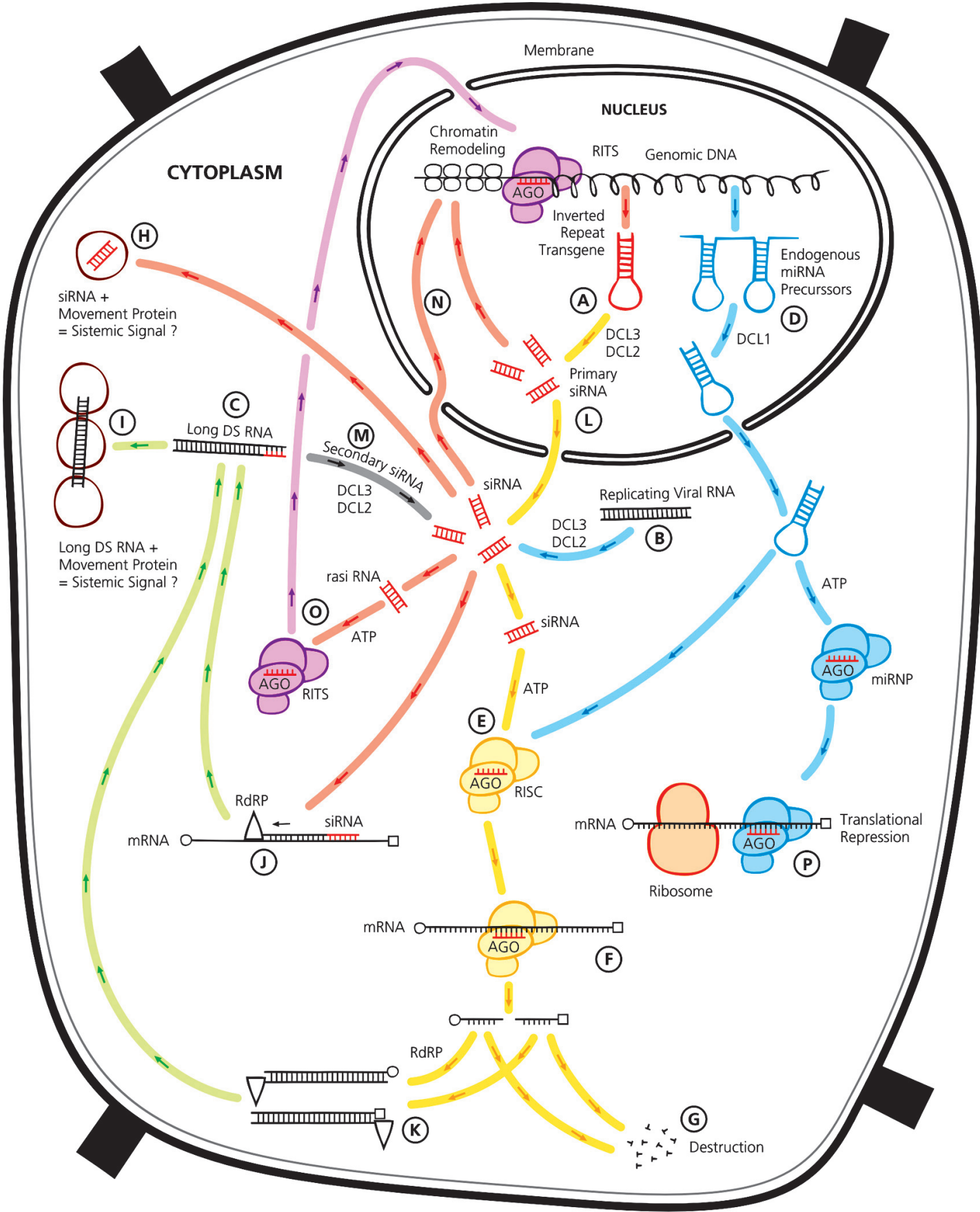

Figure 1 - Gene Silencing pathways in plant cells. (A) Dicer-like protein (DCL2, DCL3) processing of transcripts containing inverted repeats (Meister \& Tuschl, 2004); (B) Dicer-like protein (DCL2, DCL3) processing of intermediates formed during RNA virus replication (Hannon, 2002); (C) Long dsRNA; (D) Dicer-like protein (DCL1) processing of miRNAs precursors (Xie et al., 2004); (E) RNA-induced silencing complex (RISC) (Hammond et al., 2000; Nykänen et al., 2001); (F) Targeting and cleavage of sequence specific mRNA by RISC (Martinez \& Tuschl, 2004); (G) mRNA destruction after RISC processing (Tolia \& Joshua-Tor, 2006); (H) Possible systemic signal composed by siRNA + movement proteins; (I) Possible systemic signal composed by long dsRNA + movement proteins (Waterhouse et al., 2001); (J) Primer dependent RdRP amplification (Matzke et al., 2001; Ceruti, 2003; Baulcombe, 2004); (K) Primer-independent (aberrant RNA features) RdRP amplification (Baulcombe, 2004); (L) Primary siRNA (Pak \& Fire, 2007); (M) Secondary siRNA processing by Dicer-like enzymes (Pak \& Fire, 2007); (N) RNA-directed DNA methylation (RdDM) signal transmitted from the cytoplasm to the nucleus is most likely siRNA (Xie et al., 2004); (O) RNAi effector complex termed RITS (RNA-induced Initiation of Transcriptional gene Silencing) required for heterochromatin assembly in fission yeast (Schizosaccharomyces pombe) (Verdel et al., 2004). RITS is composed by repeat-associated short interfering RNA (rasiRNA) (Meister \& Tuschl, 2004); (P) Translational repression of mRNA by miRNP (Meister \& Tuschl, 2004). 
ated by recombinant viral vectors (Ruiz et al., 1998). The model includes viral dependent initiation and viral independent maintenance of VIGS. The approach consists of cloning and inserting plant endogenous gene sequences in recombinant viral vectors, which are then inoculated in plants, triggering PTGS / RNAi. This ends up silencing plant genes with homologous sequences to those contained in the viral vectors (BurchSmith et al., 2004).

In early approaches on VIGS studies, gene sequences were individually subcloned into viral genomes, and plants were physically inoculated using viral RNA produced by in-vitro transcriptional reactions (Kumagai et al., 1995). The previously described technique is time consuming and produces variable results, only being used when dealing with limited number of genes (Burch-Smith et al., 2004). An easier method for plant infection would be the use of agroinfiltration of viral cloned vectors (Robertson, 2004). VIGS protocols can be optimized by the insertion of viral RNA genomes in binary vectors for agroinfiltration (Ratcliff et al., 2001). This technique uses Agrobacterium tissue infiltration for T-DNA transfer of encoded genes that will be transferred into the cells of the infiltrated region, and transcribed into the viral cDNAs, these transcripts would then serve as inocula to initiate systemic infection of the plant (Ratcliff et al., 2001). The use of this form of viral inoculation has the advantage of not having to produce in-vitro viral transcripts.

VIGS is a powerful tool due to its fast initiation of silencing in intact wild-type or transgenic plants (Robertson, 2004). VIGS has been utilized to investigate individual gene and gene family functions (BurchSmith et al., 2004). Phenotypic variations attributed to gene suppression by VIGS can be obtained in a relatively short period of time. It is possible to silence genes in mature plants using this technique. Therefore, no plant transformation is necessary since the silencing is induced by the viral infection. The limitation of this approach resides in the viral host range, pattern of viral spreading, and symptoms caused by the infection.

\section{APPLICATIONS OF GENE SILENCING IN WOODY PLANTS}

Yield of woody plants is a result of growth that depends on several aspects of the physiological machinery (Kozlowski et al., 1991). GS is a powerful tool in an attempt to better understand the organization of this machinery, specially regarding biochemical pathways and gene function. Woody plants have great economic importance in agriculture and economy of several countries in the world. Wood, celulose, fruit, resins, rubber, oils and nuts are some of the products de- rived from woody plants. In order to guarantee the sustainability of woody crops, it is necessary to keep the high quality and yield levels. For these purposes, conventional breeding programs have been extensively conducted. However, these programs have not been enough to supply short-termed solutions for these crops. Woody plants normally have slower growth rates than herbaceous plants as well as longer juvenile periods. These characteristics speeds down breeding projects in this area. Similar problems occur in woody fruit crop breeding as well as others such as highly heterozygous material, polyploidy, nucellar polyembryony, pollen and ovule sterility, and sexual incompatibility, which have limited progress towards the production of new cultivars through conventional breeding programs (Janick \& Moore, 1975; Costa et al., 2003).

The introduction of biotechniques in breeding programs for woody plants was motivated by the search for pest and disease resistance and to fulfill the demands of the consumer market. Transgenesis is an important alternative for engineering traits into forest trees and developing basic research in gene function (Kumar \& Fladung, 2003). In this scenario, genetic transformation came into context and, consequently, the aplication of GS technology.

After the genetic transformation of the first model plant (tobacco) (Herrera-Estrella et al., 1983) as well as other rapid growing species, the next step was to obtain transgenic woody plants. This has proven to be a though challenge since woody plants are harder to transform and require a long evaluation process. More than 16 species of woody plants were transformed between 1988 and 2000 (Rautner, 2001). These transformations were focused on several traits such as herbicide resistance, insect resistance, virus resistance, lignin biosynthesis, marker genes, and self-sterility suppression. Some of these traits are obtained by specific transgene expression into proteins. However, others are achieved by silencing of transgenes or endogenous genes.

Some of the woody plant species that have been used in GS research includes Citrus aurantifolia (Christ.) Swing. (Domínguez et al., 2002b; Fagoaga et al., 2006), Prunus sp. (Ravelonandro et al., 2000; Scorza et al., 2001; Hily et al., 2004; 2005; Di Nicola-Negri et al., 2005; Zhang et al., 2006), Populus sp. (Jouanin et al., 2000; Kumar \& Fladung, 2001; Hawkins et al., 2003), Solanum dulcamara L. (Curtis et al., 2000), Malus domestica Borkh. (Ko et al., 1998; Dandekar et al., 2004; Viss et al., 2003; Broothaerts et al., 2004; Gilissen et al., 2005; Teo et al., 2006), Pinus radiata D. Don. (Moller et al., 2005; Tang et al., 2005a; 2005b; Wagner et al., 2005; Tang et al., 2006), Juglans regia 
L. (Escobar et al., 2002), Coffea canephora (Ogita et al., 2003), Eucalyptus sp. (Valério et al., 2003; Sassaki et al., 2005), Caryca papaya (Tennant et al., 2001), and Actinidia deliciosa (A.Chev.) C.F. Liang et A.R. Ferguson (Fung et al., 1998).

\section{GENE SILENCING AND PLANT DISEASE RESIS- TANCE}

Woody crops are particularly susceptible to systemic virus diseases because of their long-term life span. Once infected by viruses, these plants must be rouged. Virus disease resistance in plants may be achieved by several approaches, including coat protein mediated protection (Fitch et al., 1992), antisense RNA, replicase mediated protection (Romano \& Monte, 1999), PTGS (Lindbo \& Dougherty, 1992), RNAi, and pathogen derived resistance (PDR) (Sanford \& Johnston, 1985). The concept of PDR suggests that the resistance to a determined pathogen could be obtained from its own genetic material. The quest for virus resistant plants led researchers to accidentally discover the PTGS phenomenon (Angell \& Baulcombe, 1997) and aid the establishment of RNAi models. Currently, RNAi is the major strategy in plant transformation for virus resistance. Citrus tristeza virus (CTV) resistant citrus plants, expressing the coat protein of the virus has been obtained (Domínguez et al., 2000; Domínguez et al., 2002a). In this work, virus resistance was related to the accumulation of the transgenic viral protein in the plant tissue. The mechanism proposed was pathogen derived resistance.

Scorza et al. (2001) demonstrated for the first time that PTGS (RNAi) functions as a mechanism for virus resistance in a woody perennial species. They obtained resistant transgenic plums containing the silenced Plum pox virus (PPV) coat protein gene. Signs of PTGS could be observed within the resistant plants such as high level of transgene transcription in the nucleus, low levels of transgene mRNA in the cytoplasm, a complex multicopy transgene insertion with aberrant copies, and methylation of the silenced PPV$\mathrm{CP}$ transgene. Other strategies such as the expression of PPV-specific hairpins in plums have also been effective (Di Nicola-Negri et al., 2005; Zhang et al., 2006). In another case, transgenic viral protein accumulation was negatively correlated to resistance. Silenced transgenic citrus lines for the p23 CTV - silencing suppressor were resistant to CTV. PTGS seems to be the best explanation for these results since resistant citrus plants had multiple copies of the transgene, low levels of the corresponding mRNA, methylation of the silenced transgene, and accumulation of the p23-specific small interfering RNAs (siRNAs) (Fagoaga et al., 2006).
Despite of the potential application of GS as a viral defense system, there is a drawback. Viruses have developed RNAi suppression strategies during co-evolution with plants. The main strategy used by both RNA and DNA viruses is the incorporation of silencing suppressor proteins into their genomes (Moissiard \& Voinnet, 2004). It is suggested that dsRNA binding is one of the main strategies used by viral silencing suppressors. The model proposes the sequestering of long and/or short dsRNA molecules preventing the proper functioning of the RNA silencing pathways (Merai et al., 2006). CTV, for instance, is known to contain at least three distinct suppressors of RNAi. Proteins p20, p23, and the coat protein act in different stages of RNAi, affecting both intercellular (p20 and coat protein) and intracellular (p20 and p23) silencing (Lu et al., 2004). RNAi suppressor proteins can alter the pattern of gene expression in virus hosts, since they affect both miRNA and siRNA pathways, leading to developmental abnormalities and possibly viral symptoms (Voinnet, 2005). Ectopic expression of the CTV p23 gene in Mexican limes (Citrus aurantifolia (Christ.) Swing.) caused aberrations resembling viral leaf symptoms (Fagoaga et al., 2006). In order to obtain virus resistant plants through GS techniques it is important to understand all of the viral counter defense strategies.

Silencing has also been applied in an effort to protect plants against the crown gall disease, caused by Agrobacterium tumefaciens (Escobar et al., 2001). This disease is economically important in fruit and nut orchards, vineyards, and nurseries (Viss et al., 2003). A protection technique based on the silencing of two conserved Agrobacterium genes - tryptophan monooxygenase (iaaM) and isopentenyl transferase (ipt) - have been developed (Escobar et al., 2001; 2002). Inducers of PTGS (self complementary transgenes) homologous to iaaM and ipt were expressed in Juglans regia L., resulting in degradation of oncogene mRNA in planta and functional resistance. Crown gall resistant apple tree roots were obtained by transformation with transgenes designed to express double-stranded RNA from the iaaM and ipt genes (Viss et al., 2003).

\section{GENE SILENCING AND WOOD QUALITY, FRUIT QUALITY AND OTHER TRAITS}

During chemical pulping of wood, one of the most expensive and environmentally hazardous processes is to separate lignin from cellulose and hemicellulose (Pilate et al., 2002). The production of plant material with lower contents of lignin would mean a significant reduction of cost and pollution to the paper industry. One of the approaches to obtain reduced lignin forest trees has been the down regulation of lignin 
biosynthesis pathways (Hu et al., 1999). The main genes involved with genetic transformation targeting lignin reduction are 4-coumarate: coenzyme A ligase (Pt4CL1) (Hu et al., 1999), cynnamyl alcohol deshydrogenase (CAD - the final enzyme in the biosynthesis of lignin monomers) (Baucher et al., 1996) and caffeate/5-hydroxyferulate O-methyltransferase (COMT - enzyme involved in syringyl lignin synthesis) (Lapierre et al., 1999).

The downregulation of the Pt4CL1 gene in Populus tremuloides Michx., produced trees with a $45 \%$ reduction of the lignin content compensated by a $15 \%$ increase in the cellulose content. In the transgenic lines obtained plant growth was substantially enhanced, and structural integrity maintained both at the cellular and whole-plant levels (Hu et al., 1999).

Silencing was also registered when trying to boost up the expression of the caffeic acid Omethyltransferase (COMT) in Populus tremula $X$ Populus alba. On some transgenic lines, silencing of the transgene was observed, and the down regulation of COMT reduced the lignin levels in 6-month-old Populus tremula $X$ Populus alba. This was the first report of lignin reduction in COMT down regulated plants (Jouanin et al., 2000).

Cad GS by transgenic inverted repeats has been reported in Pinus radiata (Wagner et al., 2005). The authors also suggested that there are similar mechanisms of GS for angiosperms and gymnosperms species. In order to become rate limiting in lignin biosynthesis, CAD levels must be significantly reduced in Pinus radiata and conifers (Moller et al., 2005). In Eucalyptus camaldulensis the reduction of CAD activity by using antisense transgenes did not result in lignin reduction in transformed plants (Valério et al., 2003).

In some woody plants, self-incompatibility stands as a major problem in fruit set and breeding programs. Broothaerts et al. (2004), reported the production of transgenic apple trees able to self pollinate and develop fruit. This break through was achieved by silencing of the S-gene responsible for self-incompatibility. The self-compatible transgenic plants lacked the pistil $\mathrm{S}$-RNase protein, which is the product of the S-gene.

Fruit quality has also been addressed by silencing experiments. Several characteristics are involved in fruit quality. Transgenic apple fruits silencing key enzymes involved in autocatalytic ethylene production were significantly firmer and displayed an increased shelf-life (Dandekar et al., 2004). Apples containing reduced amounts of the Mal d 1 allergen were obtained by the expression of an intron spliced hairpin RNA containing Mal d 1-specific inverted repeat sequences (Gilissen et al., 2005). According to these reports, it is possible to produce transgenic hypoallergenic apples using RNAi. Research on leaf sorbitol silencing suggests that sorbitol distribution affects fruit quality such as starch accumulation and sugar-acid balance (Teo et al., 2006). In Citrus, the down regulation of putative thermostable pectin methylesterase genes is projected as a possible solution for the undesirable separation of juice into clear serum and particulate phase (Guo et al., 2005). In this case, RNAi could be used to achieve this goal.

\section{FINAL REMARKS AND PERSPECTIVES}

GS techniques represent great opportunities for plant breeding. Several practical applications in economically important crops are possible as well as research on gene function and expression. So far, the basic pathways of gene silencing in plants have been described as shown in this work. There is still much to investigate such as the molecular structures of the proteins involved, the nature of the systemic signal and the stability of these pathways in a given time frame.

RNAi stability in plants is a very important feature to be accessed in the near future as well as the development of tissue specific and inducible promoters. These are two crucial points for the establishment of this technology as a marketable option. Control of metabolic pathways will also represent a major challenge when trying to obtain plants with altered levels of specific metabolites. The use of artificial miRNA to engineer viral resistant plants also shows great potential.

Continuing research on GS in woody plants will probably include plant protection to multiple pathogens (viruses, bacteria), silencing of specific metabolic pathways (lignin synthesis, ethylene, allergens, caffeine and others), improvement of fruit and wood quality, production of secondary metabolites, and developmental and reproductive trait alteration in plants (induced male sterility and self-compatibility). The ability to switch off genes and interfere with expression patterns in plants, provided by gene silencing techniques, will probably represent a great impact in woody plant breeding.

\section{ACKNOWLEDGEMENTS}

To Dr. Leandro Peña and Dr. Rogério Margis for critical comments and suggestions, and Fernanda dos Santos Pereira de Souza for technical assistance and graphical design to elaborate Figure 1.

\section{REFERENCES}

ALBERTS, B.; JOHNSON, A.; LEWIS, J.; RAFF, M.; ROBERTS, K.; WALTER, P. Molecular biology of the cell. 4.ed. New York: Garland Science, 2002. 1463p. 
ANGELL, S.M.; BAULCOMBE, D.C. Consistent gene silencing in transgenic plants expressing a replicating potato virus X RNA. The EMBO Journal, v.16, p.3675-3684, 1997.

AUKERMAN, M.J.; SAKAI, H. Regulation of flowering time and floral organ identity by a microRNA and its APETALA2-like target genes. The Plant Cell, v.15, p.2730-3741, 2003.

BARTEL, D.P. MicroRNAs: genomics, biogenesis, mechanism and function. Cell, v.116, p.281-297, 2004.

BARTEL, B.; BARTEL, D.P. MicroRNAs: At the root of plant development? Plant Physiology, v.132, p.709-717, 2003.

BAUCHER, M.; CHABBERT, B.; PILATE, G.; VAN DOORSSELAERE, J.; TOLLIER, M.T.; PETIT-CONIL, M.; CORNU, D.; MONTIES, B.; VAN MONTAGU, M.; INZE, D.; JOUANIN, L.; BOERJAN, W. Red xylem and higher lignin extractability by down-regulating a cinnamyl alcohol dehydrogenase in Poplar. Plant Physiology, v.112, p.14791490, 1996.

BAULCOMBE, D.C. RNA silencing in plants. Nature, v.431, p.356-363, 2004.

BAULCOMBE, D.C. Amplified silencing. Science, v.315, p.199200, 2007.

BERNSTEIN, E.; CAUDY, A.A.; HAMMOND, S.M.; HANNON, G.J. Role for a bidentate ribonuclease in the initiation step of RNA interference. Nature, v.409, p.363-366, 2001.

BONNET, E.; DE PEER, Y.V.; ROUZE, P. The small RNA world of plants. New Phytologist, v.171, p.451-468, 2006.

BRIGNETI, G.; VOINNET, O.; LI, W.; JI, L.; DING, S.; BAULCOMBE, D.C. Viral pathogenicity determinants are suppressors of transgene silencing in Nicotiana benthamiana. The EMBO Journal, v.17, p.6739-6746, 1998.

BROOTHAERTS, W.; KEULEMANS, J.; VAN NERUM, I. Selffertile apple resulting from S-RNase gene silencing. Plant Cell Reports, v.22, p.497-501, 2004.

BURCH-SMITH, T.M.; ANDERSON, J.C.; MARTIN, G.B.; DINESH-KUMAR, S.P. Applications and advantages of virusinduced gene silencing for gene function studies in plants. The Plant Journal, v.39, p.734-746, 2004.

CERUTTI, H. RNA interference: traveling in the cell and gaining functions? Trends in Genetics, v.19, p.39-46, 2003

CHAN, S.W.L.; ZILBERMAN, D.; XIE, Z.; JOHANSEN, L.K.; CARRINGTON, J.C.; JACOBSEN, S.E. RNA silencing genes control de novo DNA methylation. Science, v.303, p.1336, 2004.

CHEN, X. A microRNA as a translational repressor of APETALA2 in Arabidopsis flower development. Science, v.303, p.20222025, 2004.

COGONI, C.; MACINO, G. Isolation of quelling-defective (qde) mutants impaired in posttranscriptional transgene-induced gene silencing in Neurospora crassa. Proceedings of the National Academy of Science of the USA, v.94, p.1023310238, 1997.

COSTA, M.A.P. de C.; MENDES, B.J.M.; MOURÃO FILHO, F.A.A. Somatic hybridization for improvement of citrus rootstocks: production of five new combinations with potential for improved disease resistance. Australian Journal of Experimental Agriculture, v.43, p.1151-1156, 2003.

CURTIS, I.S.; POWER, J.B.; HEDDEN, P.; PHILLIPS, A.; LOWE, K.C.; WARD, D.A.; DAVEY, M.R. Transformation and characterization of transgenic plants of Solanum dulcamara L. - Incidence of transgene silencing. Annals of Botany, v.86, p.63-71, 2000.

DANDEKAR, A.M.; TEO, G.; DEFILIPPI, B.G.; URATSU, S.L.; PASSEY, A.J.; KADER, A.A.; STOW, J.R.; COLGAN, R.J.; JAMES, D.J. Effect of down-regulation of ethylene biosynthesis on fruit flavor complex in apple fruit. Transgenic Research, v.13, p.373-384, 2004.

DANeholt, B. The Nobel Prize in Physiology or Medicine 2006 - Advanced Information. Available at: http:// nobelprize.org/nobel_prizes/medicine/laureates/2006/adv.html. Accessed at: 14 fev. 2007.
DAVULURI, G.R.; VAN TUINEN, A.; FRASER, P.D.; MANFREDONIA, A.; NEWMAN, R.; BURGESS, D.; BRUMMELL, D.A.; KING, S.R.; PALYS, J.; UHLIG, J.; BRAMLEY, P.M.; PENNINGS, H.M.J.; BOWLER, C. Fruitspecific RNAi-mediated suppression of DET1 enhances carotenoid and flavonoid content in tomatoes. Nature Biotechnology, v.23, p.890-895, 2005.

DAWE, R.K. RNA interference, transposons, and the centromere. The Plant Cell, v.15, p.297-301, 2003.

DI NICOLA-NEGRI, E.; BRUNETTI, A.; TAVAZZA, M.; ILARDI, V. Hairpin RNA-mediated silencing of Plum pox virus P1 and HC-Pro genes for efficient and predictable resistance to the virus. Transgenic Research, v.14, p.989-994, 2005.

DOMÍNGUEZ, A.; DE MENDOZA, A.H.; GUERRI, J.; CAMBRA, M.; NAVARRO, L.; MORENO, P.; PEÑA, L. Efficient production of transgenic citrus plants expressing the coat protein gene of citrus tristeza virus. Plant Cell Reports, v.19, p.427433, 2000.

DOMÍNGUEZ, A.; DE MENDOZA, A.H.; GUERRI, J.; CAMBRA, M.; NAVARRO, L.; MORENO, P.; PEÑA, L. Pathogen-derived resistance to Citrus tristeza virus (CTV) in transgenic Mexican lime (Citrus aurantifolia (Christ.) Swing.) plants expressing its p25 coat protein gene. Molecular Breeding, v.10, p.1-10, $2002 \mathrm{a}$

DOMÍNGUEZ, A.; FAGOAGA, C.; NAVARRO, L.; MORENO, P.; PEÑA, L. Regeneration of transgenic citrus plants under non selective conditions results in high-frequency recovery of plants with silenced transgenes. Molecular Genetics Genomics, v.267, p.544-556, 2002b.

DUAN, C.G.; WANG, C.H.; GUO, H.S. Regulation of microRNA on plant development and viral infection. Chinese Science Bulletin, v.51, p.269-278, 2006.

ELBASHIR, S.M., LENDECKEL, W.; TUSCHL, T. RNA interference is mediated by 21 and 22 nt RNAs. Genes $\&$ Development. v.15, p.188-200, 2001.

EMERY, J.F.; FLOYD, S.K.; ALVAREZ, J.; ESHED, Y.; HAWKER, N.P.; IZHAKI, A.; BAUM, S.F.; BOWMAN, J.L. Radial patterning of Arabidopsis shoots by class III HD-ZIP and KANADI genes. Current Biology, v.13, p.1768-1774, 2003.

ESCOBAR, M.A.; CIVEROLO, E.L.; SUMMERFELT, K.R.; DANDEKAR, A.M. RNAi-mediated oncogene silencing confers resistance to crown gall tumorigenesis. Proceedings of the National Academy of Science of the USA, v.98, p.1343713442, 2001.

ESCOBAR, M.A.; LESLIE, C.A.; MCGRANAHAN, G.H.; DANDEKAR, A.M. Silencing crown gall disease in walnut (Julgans regia L.). Plant Science, v.163, p.591-597, 2002.

FAGOAGA, C.; LÓPEZ, C.; De MENDOZA, A.H.; MORENO, P.; NAVARRO, L.; FLORES, R.; PEÑA, L. Post-transcriptional gene silencing of the p23 silencing suppressor of Citrus tristeza virus confers resistance to the virus in transgenic Mexican lime. Plant Molecular Biology, v.60, p.153-165, 2006.

FIRE, A.; XU, S.; MONTGOMERY, M.K.; KOSTAS, S.A.; DRIVER, S.E.; MELLO, C.C. Potent and specific genetic interference by double-stranded RNA in Caenorhabditis elegans. Nature, v.391, p.806-811, 1998.

FITCH, M.M.M.; MANSHARDT, R.M.; GONSALVES, D.; SLIGHTOM, J.L.; SANFORD, J.C. Virus resistant papaya plants derived from tissues bombarded with the coat protein gene of papaya ringspot virus. Nature Biotechnology, v.10, p.14661472, 1992

FRAGA, M.F.; RODRIGUEZ, R.; CANAL, M.J. Genomic DNA methylation-demethylation during aging and reinvigoration of Pinus radiata. Tree Physiology, v.22, p.813-816, 2002.

FUNG, R.W.M.; JANSSEN, B.J.; MORRIS, B.A.; GARDNER, R.C. Inheritance and expression of transgenes in kiwifruit. New Zealand Journal of Crop and Horticultural Science, v.26, p.169-179, 1998.

GALUN, E. RNA silencing in plants. In Vitro Cellular \& Developmental Biology -Plant, v.41, p.113-123, 2005. 
GILISSEN, L.J.W.J.; BOLHAAR, S.T.H.; MATOS, C.I.; ROUWENDAL, G.J.A.; BOONE, M.J.; KRENS, F.A.; ZUIDMEER, L.; VAN LEEUWEN, A.; AKKERDAAS, J.; HOFFMANN-SOMMERGRUBER, K.; KNULST, A.C.; BOSCH, D.; VAN DE WEG, W.E.; VAN REE, R. Silencing of the major apple allergen Mal 1 by using RNA interference approach. Journal of Allergy and Clinical Immunology, v.115, p.364$369,2005$.

GRIFFITHS, A J.F.; MILLER, J.H.; SUZUKI, D.T.; LEWONTIN, R.C. GELBART, W.M. Introdução à genética. 6.ed. Rio de Janeiro: Guanabara Koogan, 1998. 856p.

GUO, W.; DUAN, Y.; OLIVARES-FUSTER, O.; WU, Z.; ARIAS, C.R.; BURNS, J.K.; GROSSER, J.W. Protoplast transformation and regeneration of transgenic Valencia sweet orange plants containing a juice quality-related pectin methylesterase. Plant Cell Reports, v.24, p.482-486, 2005.

GURA, T. A silence that speaks volumes. Nature, v.404, p.804808,2000

GUTIÉRREZ-E, M.A.; LUTH, D.; MOORE, G.A. Factors affecting agrobacterium-mediated transformation in Citrus and production of sour orange (Citrus aurantium L.) plants expressing the coat protein gene of citrus tristeza virus. Plant Cell Reports, v.16, p.745-753, 1997.

HAMILTON, A.J.; BAULCOMBE, D.C. A species of small antisense RNA in posttranscriptional gene silencing in plants. Science, v.286, p.950-952, 1999.

HAMMOND, S.M.; BERNSTEIN, E.; BEACH, D.; HANNON, G.J. An RNA-directed nuclease mediates post-transcriptional gene silencing in Drosophila cells. Nature, v.404, p.293-296, 2000.

HAMMOND, S.M.; BOETTCHER, S.; CAUDY, A.A.; KOBAYASHI, R.; HANNON, G.J. Argonaute2, a link between genetic and biochemical analyses of RNAi. Science, v.293, p.1146-1150, 2001

HANNON, G.J. RNA interference. Nature, v.418, p.244-251, 2002

HAWKINS, S.; LEPLE, J.C.; CORNU, D.; JOUANIN, L.; PILATE, G. Stability of transgene expression in poplar: A model forest tree species. Annals of Forest Science, v.60, p.427-438, 2003.

HENDERSON, I.R.; ZHANG, X.; LU, C.; JOHNSON, L.; MEYERS, B.C.; GREEN, P.J.; JACOBSEN, S.E. Dissecting Arabidopsis thaliana DICER function in small RNA processing, gene silencing and DNA methylation patterning. Nature Genetic, v.38, p.721-725, 2006.

HERRERA-ESTRELLA, L.; DEPICKER, A.; VAN MONTAGU, M.; SCHELL, J. Expression of chimeric genes transferred into plant cells using a Ti-plasmid-derived vector. Nature, v.303, p.209-213, 1983.

HILY, J.M.; SCORZA, R.; MALINOWSKI, T.; ZAWADZKA, B.; RAVELONANDRO, M. Stability of gene silencing-based resistance to Plum pox virus in transgenic plum (Prunus domestica L.) under field conditions. Transgenic Research, v.13, p.427-436, 2004.

HILY, J.M.; SCORZA, R.; WEBB, K.; RAVELONANDRO, M. Accumulation of the long class of siRNA is associated with resistance to Plum pox virus in a transgenic woody perennial plum tree. Molecular Plant-Microbe Interactions, v.18, p.794-799, 2005.

HU, W.; HARDING, S.A.; LUNG, J.; POPKO, J.L.; RALPH, J.; STOKKE, D.D.; TSAI, C.; CHIANG, V.L. Repression of lignin biosynthesis promotes cellulose accumulation and growth in transgenic trees. Nature Biotechnology, v.17, p.808-812, 1999.

JOUANIN, L.; GOUJON, T.; DE NADAI, V.; MARTIN, M.T.; MILA, I.; VALLET, C.; POLLET, B.; YOSHINAGA, A.; CHABBERT, B.; PETIT-CONIL, M.; LAPIERRE, C. Lignification in transgenic poplars with extremely reduced caffeic acid O-methyltransferase activity. Plant Physiology, v.123, p.1363-1373, 2000

JANICK, J.; MOORE, J.N. Advances in fruit breeding. West Lafayette: Purdue University Press, 1975. 623p.
KHVOROVA, A.; REYNOLDS, A.; JAYASENA, S. D. Functional siRNA and miRNA exhibit strand bias. Cell, v.115, p.209-216, 2003.

KO, K.; BROWN, S.K.; NORELLI, J.L.; ALDWINCKLE, H.S. Alterations in nptIIand gus expression following micropropagation of transgenic M7 apple rootstock lines. Journal of the American Society for Horticultural Science, v.123, p.11-18, 1998.

KOOTER, J.M.; MATZKE, M.A.; MEYER, P. Listening to the silent genes: transgene silencing, gene regulation and pathogen control. Trends in Plant Science, v.4, p.340-347, 1999.

KOZLOWSKI, T.T.; KRAMER, P.J.; PALLARDY, S.G. The physiological ecology of woody plants. San Diego: Academic Press, 1991. 657p.

KUMAGAI, M.H.; DONSON, J.; DELLACIOPPA, G.; HARVEY, D.; HANLEY, K.; GRILL, L.K. Cytoplasmic inhibition of carotenoid biosynthesis with virus-derived RNA. Proceedings of the National Academy of Science of the USA, v.92, p.1679-1683, 1995

KUMAR, S.; FLADUNG, M. Gene stability in transgenic aspen (Populus). II. Molecular characterization of variable expression of transgene in wild and hybrid aspen. Planta, v.213, p.731$740,2001$.

KUMAR, D.; FLADUNG, M. Forest tree transgenesis and functional genomics: From fast forward to reverse genetics. Silvae Genetica, v.52, p.229-232, 2003.

LAPIERRE, C.; POLLET, B.; PETIT-CONIL, M.; TOVAL, G.; ROMERO, J.; PILATE, G.; LEPLÉ, J.; BOERJAN, W.; FERRET, V.; DE NADAI, V.; JOUANIN, L. Structural alterations of lignins in transgenic poplars with depressed cinnamyl alcohol dehydrogenase or caffeic acid $O$-methyltransferase activity have an opposite impact on the efficiency of industrial kraft pulping. Plant Physiology, v.119, p.153-164, 1999.

LEE, R.C.; FEINBAUM, R.L.; AMBROS, V. The C. elegans heteochronic gene lin-4 encodes small RNAs with antisense complementarity to lin-14. Cell, v.75, p.843-854, 1993.

LINDBO, J.A.; DOUGHERTY, W.G. Untranslatable transcripts of the tobacco etch virus coat protein gene sequence can interfere with tobacco etch virus replication in transgenic plants and protoplasts. Virology, v.189, p.725-733, 1992.

LIPPMAN, Z.; MARTIENSSEN, R. The role of RNA interference in heterochromatic silencing. Nature, v.431, p.364-370, 2004.

LODISH, H.; BERK, A.; ZIPURSKY, S.L.; MATSUDAIRA, P.; KAISER, C.A.; KREIGER, M.; SCOTT, M.P.; BALTIMORE, D.; DARNELL, J. Biologia celular e molecular. 5.ed. Porto Alegre: Artmed, 2005. 1054p.

LU, R.; FOLIMONOV, A.; SHINTAKU, M.; LI, W.; FALK, B.W.; DAWSON, W.O.; DING, S. Three distinct suppressors of RNA silencing encoded by a $20-\mathrm{kb}$ viral RNA genome. Proceeding of the National Academy of Sciences of the USA, v.101, p.15742-15747, 2004.

MANSOOR, S.; AMIN, I.; HUSSAIN, M.; ZAFAR, Y.; BRIDDON, R.W. Engineering novel traits in plants through RNA interference. Trends in Plant Science, v.11, p.559-565, 2006.

MARGIS, R.; FUSARO, A.F.; SMITH, N.A.; CURTIN, S.J.; WATSON, J.M.; FINNEGAN, E.J.; WATERHOUSE, P.M. The evolution and diversification of Dicers in plants. Federation of European Biochemical Societies Letters, v.180, p.24422450, 2006.

MARTINEZ, J.; TUSCHL, T. RISC is a 5_phosphomonoesterproducing RNA endonuclease. Genes \& Development, v.18, p.975-980, 2004.

MATZKE, M.; MATZKE, A.J.M.; KOOTER, J.M.RNA: Guiding gene silencing. Science, v.293, p.1080-1083, 2001.

MEISTER, G.; TUSCHL, T. Mechanisms of gene silencing by double-stranded RNA. Nature, v.431, p.343-349, 2004.

MERAI, Z.; KERENYI, Z.; KERTESZ, S.; MAGNA, M.; LAKATOS, L.; SILHAVY, D. Double-stranded RNA binding may be a general plant RNA viral strategy to suppress RNA silencing. Journal of Virology, v.80, p.5747-5756, 2006. 
MOISSIARD, G. VOINNET, O. Viral suppression of RNA silencing in plants. Molecular Plant Pathology, v.5, p.71-82, 2004.

MOLLER, R.; STEWARD, D.; PHILLIPS, L.; FLINT, H.; WAGNER, A. Gene silencing of cinnamyl alcohol dehydrogenase in pinus radiata callus cultures. Plant Physiology and Biochemistry, v.43, p.1061-1066, 2005.

NAPOLI, C.; LEMIEUX, C.; JORGENSEN, R. Introduction of a chimeric chalcone synthase gene into petunia results in reversible co-suppression of homologous genes in trans. The Plant Cell, v.2, p.279-289, 1990 .

NIU, Q.W.; LIN, S.S.; REYES, J.L.; CHEN, K.C.; WU, H.W.; YEH, S.D.; CHUA, N.H. Expression of artificial microRNAs in transgenic Arabidopsis thaliana confers virus resistance. Nature Biotechnology, v.24, p.1420-1428, 2006.

NYKÄNEN, A.; HALEY, B.; ZAMORE, P.D. ATP requirements and small interfering RNA structure in the RNA interference pathway. Cell, v.107, p.309-321, 2001.

OGITA, S.; UEFUJI, H.; YAMAGUCHI, Y.; KOIZUMI, N.; SANO, H. RNA interference: Producing decaffeinated coffee plants. Nature, v.423, p.823, 2003.

PAK, J.; FIRE, A. Distinct populations of primary and secondary effectors during RNAi in C. elegans. Science, v.315, p.241244, 2007.

PALATNIK, J.F.; ALLEN, E.; WU, X.; SCHOMMER, C.; SCHWAB, R.; CARRINGTON, J.C.; WEIGEL, D. Control of leaf morphogenesis by microRNAs. Nature, v.425, p.257-263, 2003.

PAPP, I.; METTE, M.F.; AUFSATZ, W.; DAXINGER, L.; SCHAUER, S.E.; RAY, A.; VAN DER WINDEN, J.; MATZKE, M.; MATZKE, A.J.M. Evidence for nuclear processing of plant micro RNA and short Interfering RNA precursors. Plant Physiology, v.132, p.1382-1390, 2003.

PILATE, G.; GUINEY, E.; HOLT, K.; PETIT-CONIL, M.; LAPIERRE, C.; LEPLÉ, J.; POLLET, B.; MILA, I.; WEBSTER, E.A.; MARSTORP, H.G.; HOPKINS, D.W.; JOUANIN, L.; BOERJAN, W.; SCHUCH, W.; CORNU, D.; HALPIN, C. Field and pulping performances of transgenic trees with altered lignification. Nature Biotechnology, v.20, p.607-612, 2002.

RATCLIFF, F.; MARTIN-HERNANDEZ, A.M.; BAULCOMBE, D.C. Tobacco rattle virus as a vector for analysis of gene function by silencing. The Plant Journal, v.25, p.237-245, 2001.

RAUTNER, M. Designer trees. Biotechnology and Development Monitor, v.44, p.2-7, 2001.

RAVELONANDRO, M.; SCORZA, R.; CALLAHAN, A.; LEVY, L.; JACQUET, C.; MONSION, M.; DAMSTEEGT, V. The use of transgenic fruit trees as a resistance strategy for virus epidemics: the plum pox (sharka) model. Virus Research, v.71, p.63-69, 2000.

REINHART, B.J.; WEINSTEIN, E.G.; RHOADES, M.W.; BARTEL, B.; BARTEL, D.P. MicroRNAs in plants. Genes \& Development. v.16, p.1616-1626, 2002.

RHOADES, M.W.; REINHART, B.J.; LIM, L.P.; BURGE, C.B.; BARTEL, B.; BARTEL, D.P. Prediction of plant microRNA targets. Cell, v.110, p.513-20, 2002.

ROBERTSON, D. VIGS vectors for gene silencing: many targets, many tools. Annual Review in Plant Biology, v.55, p.495519, 2004.

ROMANO, N.; MACINO, G. Quelling: transient inactivation of gene expression in Neurospora crassa by transformation with homologous sequences. Molecular Microbiology, v.6, p.33433353, 1992.

ROMANO, E.; MONTE, D.C. Plantas transgênicas resistentes a vírus. In: TORRES, A.C.; CALDAS, L.S; BUSO, J.A. Cultura de tecidos e transformação genética de plantas. Brasília: Embrapa Hortaliças, 1999. v.2, p.783-814.

RONEMUS, M.; VAUGHN, M.V.; MARTIENSSEN, R.A. MicroRNA-targeted and small interfering RNA-mediated mRNA degradation is regulated by Argonaute, Dicer and RNA-dependent RNA polymerase in Arabidopsis. Plant Cell, v.18, p.15591574, 2006.
RUIZ, M.T.; VOINNET, O.; BAULCOMBE, D.C. Initiation and Maintenance of Virus-Induced Gene Silencing. The Plant Cell, v.10, p.937-946, 1998.

SANFORD, J.C.; JOHNSTON, S.A. The concept of parasite-derived resistance - deriving resistance genes from the parasites own genome. Journal of Theoretical Biology, v.113, p.395-405, 1985.

SASSAKI, F.T.; CAMPOS-PEREIRA, T.; MAIA, I de G. The posttranscriptional gene silencing pathway in Eucalyptus. Genetics and Molecular Biology, v.28, p.496-500, 2005.

SCHRAMKE, V.; ALLSHIRE, R. Hairpin RNAs and retrotransposon LTRs effect RNAi and chromatin-based gene silencing. Science, v.301, p.1069-1074, 2003.

SCHWARZ, D.S.; HUTVAGNER, G.; DU, T.; XU, Z.; ARONIN, N.; ZAMORE, P.D. Asymmetry in the assembly of the RNAi enzyme complex. Cell, v.115, p.199-208, 2003.

SCORZA, R.; CALLAHN, A.; LEVY, L.; DAMSTEEGT, V.; WEBB, K.; RAVELONANDRO, M. Post-transcriptional gene silencing in plum pox virus resistant European plum containing the plum pox potyvirus coat protein gene. Transgenic Research, v.10, p.201-209, 2001.

SEGAL, G.; SONG, R.T.; MESSING, J. A new opaque variant of maize by a single dominant RNA-interference-inducing transgene. Genetics, v.165, p.387-397, 2003.

TANG, W.; KINKEN, K.; NEWTON, R.J. Inducible antisensomediated post-transcriptional gene silencing in transgenic pine cells using green fluorescent protein as a visual marker. Plant and Cell Physiology, v.46, p.1255-1263, 2005a.

TANG, W.; WEIDNER, D.; NEWTON, R.J. Quantitative analysis of siRNA-mediated GFP silencing in transgenic pine cells. Plant Science, v.168, p.741-746, 2005b.

TANG, W.; NEWTON, R.J.; WEIDNER, D.A. Differential gene silencing induced by short interfering RNA in cultured pine cells associates with the cell cycle phase. Planta, v.224, p.53-60, 2006.

TENNANT, P.; FERMIN, G.; FITCH, M.M.; MANSHARDT, R.M.; SLIGHTOM, J.L.; GONSALVES, D. Papaya ringspot virus resistance of transgenic rainbow and sunup is affected by gene dosage, plant development, and coat protein homology. European Journal of Plant Pathology, v.107, p.645-653, 2001.

TEO, G.; SUZIKI, Y.; URATSU, S.L.; LAMPIEN, B.; ORMONDE, N.; HU, W.K.; DEJONG, T.M.; DANDEKAR, A.M. Silencing leaf sorbitol synthesis alters long-distance partioning and apple fruit quality. Proceeding of the National Academy of Sciences of the USA, v.103, p.18842-18847, 2006.

TOLIA, N.H.; JOSHUA-TOR, L. Slicer and the Argonautes. Nature Chemical Biology, v.3, p.36-43, 2006.

VALÉRIO, L.; CARTER, D.; RODRIGUESM, J.C.; TOURNIER, V.; GOMINHO, J.; MARQUE, C.; BOUDET, A.; MAUNDERS, M.; PEREIRA, H.; TEULIÈRES, C. Down regulation of cinnamyl alcohol dehydrogenase, a lignification enzyme, in Eucalyptus camaldulensis. Molecular Breeding, v.12, p.157167, 2003.

VAUCHERET, H.; FAGARD, M. Transcriptional gene silencing in plants: targets, inducers and regulators. Trends in Genetics, v. 17, p.29-35, 2001.

VAUCHERET, H.; BÉCLIN, C.; FAGARD, M. Post-transcriptional gene silencing in plants. Journal of Cell Science, v.114, p.3083-3091, 2001.

VAZQUEZ, F.; GASCIOLLI, V.; CRÉTÉ, P.; VAUCHERET, H. The nuclear dsRNA binding protein HYL1 is required for microRNA accumulation and plant development, but not posttranscriptional transgene silencing. Current Biology, v.14, p.346-351, 2004.

VERDEL, A.; JIA, S.; GERBER, S.; SUGIYAMA, T.; GYGI, S.; GREWAL, S.I.S.; MOAZED, D. RNAi-mediated targeting of heterochromatin by the RITS Complex. Science, v.303, p.672676, 2004. 
VISS, W.J.; PITRAK, J.; HUMANN, J.; COOK, M.; DRIVER, J.; REAM, W. Crown-gall-resistant transgenic apple trees that silence Agrobacterium tumefaciens oncogenes. Molecular Breeding, v.12, p.283-295, 2003.

VOINNET, O. Induction and suppression of RNA silencing: insights from viral infections. Nature Reviews Genetics, v.6, p.206$220,2005$.

VOINNET, O.; VAIN, P.; ANGELL, S.; BAULCOMBE, D.C. Systemic spread of sequence-specific transgene RNA degradation in plants is initiated by localized introduction of ectopic promoterless DNA. Cell, v.95, p.177-187, 1998.

VOINNET, O.; LEDERER, C.; BAULCOMBE, D.C. Viral movement protein prevents spread of the gene silencing signal in Nicotiana benthamiana. Cell, v.103, p.157-167, 2000.

WAGNER, A.; PJILLIPS, L.; NARAYAN, RD.; MOODY, J.M.; GEDDES, B. Gene silencing studies in the gymnosperm species Pinus radiata. Plant Cell Reports, v.24, p.95-102, 2005.

WASSENEGGER, M. RNA-directed DNA methylation. Plant Molecular Biology, v.43, p.203-220, 2000.

WASSENEGGER, M. Gene Silencing. International Review of Cytology, v.219, p.61-113, 2002.

WASSENEGGER, M.; PELISSIER, T. A model for RNA-mediated gene silencing in higher plants. Plant Molecular Biology, v.37, p.349-362, 1998.

WATERHOUSE, P.M.; GRAHAM, M.W.; WANG, M-B. Virus resistance and gene silencing in plats can be induced by simultaneous expression of sense and antisense RNA. Proceeding of the National Academy of Sciences of the USA, v.95, p.13959-13964, 1998.

WATERHOUSE, P.M.; WANG, M.-B; LOUGH, T. Gene silencing as an adaptative defense against viruses. Nature, v.411, p.834842,2001
WIGHTMAN, B.; HA, I.; RUVKUN, G. Posttranscriptional regulation of the heterochronic gene lin-14 3'-untranslated region are necessary to generate a temporal switch during Caenorhabditis elegans development. Gene \& Development, v.5, p.1813-1824, 1993.

XIE, Z.; JOHANSEN, L.K.; GUSTAFSON, A.M.; KASSCHAU, K.D.; LELLIS, A.D.; ZILBERMAN, D.; JACOBSEN, S.E.; CARRINGTON, J.C. Genetic and functional diversification of small RNA pathways in plants. Public Library of Science Biology, v.2, p.0642-0652, 2004

YE, F.; SIGNER, E.R. RIGS (repeat-induced gene silencing) in Arabidopsis is transcriptional and alters chromatin configuration. Proceedings of National Academy of Science of the USA, v.93, p.10881-10886, 1996.

ZHANG, S.C.; TIAN, L.M.; SVIRCEV, A.; BROWN, D.C.W.; SIBBALD, S.; SCHNEIDER, K.E.; BARSZCZ, E.S.; MALUTAN, T.; WEN, R.; SANFACON, H. Engineering resistance to Plum pox virus (PPV) through the expression of PPV-specific hairpin RNAs in transgenic plants. Canadian Journal of Plant Pathology, v.28, p.263-270, 2006.

$\overline{\text { Received July 04, }} 2007$

Accepted August 27, 2007 